der alligevel ingen tvivl om, at Jeffreys bog er et vigtigt bidrag til mange slags antropologisk litteratur om for eksempel rurale middelklasser, urbane unge, nutidens Indien, politisk lederskab og generel wheeling-dealing.

Kenneth Bo Nielsen

Antropolog, ph.d.-studerende Senter for Utvikling og Miljø

Universitetet i Oslo

\title{
LÁSZLÓ KÜRTI \& PETER SKALNÍK (eds.): Postsocialist Europe. An- thropological Perspectives from Home. Oxford: Berghahn 2009. 336 sider. ISBN 978-1-84545-474-6. Pris: $£ 50$.
}

Postsocialist Europe: Perspectives from 'Home'er en antologi med bidrag af et udvalg af antropologer med østeuropæisk baggrund. Bogens ønske er at bidrage til den antropologiske viden om det postsocialistiske Europa med krav om berettigelse og anerkendelse af ligeværd mellem øst- og vesteuropæisk antropologi. Antologien er redigeret af Lászlá Kürti og Peter Skalník og er skrevet over emnerne køn, seksualitet og national identitetsskabelse, økonomisk transformation, globalisering, rural-urban-relation, modstand, identitet og politisk transformation.

Indledningen byder på en kritik af vestlig antropologis teoretiske dominans i det antropologiske vidensfelt. Det fremhæves blandt andet, at der i (amerikanske) tidsskrifter om Østeuropa sjældent er en østeuropæisk repræsentant i redaktionen, samt at vestlige forskere, der studerer Østeuropa, burde begynde teoretiske diskussioner med at fremhæve lokale forskeres arbejde. Skalník, der er medredaktør, skriver dog i sin artikel, at begrebet „vesten“ er en emisk term, der fortjener analyse i sig selv. Den analyse synes dog svær at få øje på, men ville have gjort sig godt i opgøret med,,vestlige antropologers namedropping og elitære teoretisering“", som det påstås i bogens introduktion (s. 18, min oversættelse). Bogens fællesnævner er postsocialisme. Desværre går flere af artiklerne let hen over postsocialismen som blot en historisk baggrund i stedet for at relatere den mere direkte til de politiske og sociale fænomener, artiklerne beskriver.

Der er store udsving i kvaliteten af artiklerne med hensyn til metode, positionering og analyse. Jeg vil her komme med et par eksempler fra bidragene.

I artiklen „Migs and Cadres on the Move: Thoughts on the Mimetic Dimensions of Postsocialism" beskriver Hana Červinkova, hvordan soldaters tab af identitet hænger sammen med udskiftningen af militært udstyr, og de forskellige taktikker, soldaterne gør brug af for at holde fast i deres forståelse af sig selv og deres samfund. Udskiftningen fungerer som symbol og analogi på transitionen 
fra socialisme til kapitalisme og liberalisme, og soldaternes identitetsskabelse er en mimesis heraf.

I artiklen „Gender and Governance in Rural Communities of Postsocialist Slovakia“ beskriver Bituškova og Koštialová kvinders politiske involvering $\mathrm{i}$ landsbysamfund i det rurale Slovakiet. Den empiriske beskrivelse forklarer, at kvinder er mere aktive i mindre landsbysamfund, idet det kan sammenlignes med kvinders traditionelle roller i familien, og størrelsen af landsbyen muliggør, at kvinden stadig til en vis grad kan opfylde deres pligter i hjemmet, mens mænd fravælger politiske embeder i mindre byer, da der følger mindre prestige og indkomst med disse. Desværre diskuteres det ikke, hvordan den socialistiske fortids kønskvotienter påvirker kvinders opfattelse af deres politiske deltagelse, det står kun kort beskrevet som en historisk baggrund. Der skrives intet om, hvorvidt kvinder ønsker at besætte politiske embeder i større byer, og der savnes en generel forholden sig til „gender“ og emner såsom magt og status i forhold til køn. Til gengæld er der en hel side om forskellige epokers arkitektur, og hvordan denne ser ud i landsbyerne - uden at det relaterer sig til artiklens emne.

I artiklen „Property Relations, Class, and Labour in Rural Poland“ beskriver Michał Buchowski en landsbys økonomiske og sociale udvikling efter socialismens fald i Polen. Artiklen argumenterer for, at nye økonomiske praksisser opstår som følge af det politiske og økonomiske skift, samt at håndteringen af transitionen fra socialismen er afhængig af den enkeltes arbejdsmæssige baggrund og socioøkonomiske status. Dog savner man en diskussion af forskerens egen positionering som lokal akademiker med højere socioøkonomisk status i et lokalsamfund, hvor den socioøkonomiske sikkerhed under socialismen er byttet ud med kapitalismens hyldest af individet og frie markedskræfter.

Bogens titel henviser til det metodiske greb at studere anderledeshed, mens man ,studerer sig selv“, men til trods for indledningens løfter om denne diskussion er det i mange af artiklerne ganske ukritisk og ureflekteret konstateret, at fordi man er lokal, kan man bedre forstå de lokale forhold. Om end der nok kan være visse fordele ved at studere egen kultur/eget samfund, mangler der en decideret diskussion af, hvad ens egen positionering, status, kultur, køn etc., betyder for de indsamlede data og på den efterfølgende analyse (en undtagelse er dog Červinkovas udmærkede beskrivelse af fordele og ulemper ved at være lokal og kvinde i en militær og mandsdomineret kontekst). Selv om en diskussion af positionering i indledningen forekommer som et decideret mål med bogen, diskuterer kun tre af bogens forfattere de metodiske udfordringer og fordele ved at bedrive antropologi i eget samfund. Sammenhængen mellem indledningens ønskemål og det, der rent faktisk står i bidragene, forsvinder således desværre i et flertal af artiklerne på grund af ureflekterede konstateringer og etnografiske 
data, som henstår for sig selv uden analytisk og teoretisk kontekstualisering og refleksion.

Et gennemgående problem for bogen er, at artiklernes kvalitet varierer meget, sprogligt er flere af artiklerne ikke særligt velformulerede, men fyldt med grammatiske fejl, og få gør som lovet $\mathrm{i}$ indledningen. Som læser kunne man godt ønske sig, at der var brugt tid på en ordentlig korrekturlæsning. Dette synes især vigtigt, da indledningen kritiserer brugen af primært engelsk og fransk i antropologisk litteratur og peger på dette som årsagen til, at megen østeuropæisk etnografi og antropologi ikke er tilgængelig for vestlige forskere (EU og USA).

Der er megen interessant etnografi i bogen, men de store udsving i kvaliteten af artiklerne i forhold til udfoldelse af empiri, forklaring og validering af metode samt i forhold til analysernes kvalitet og teoriudviklende bidrag gør, at man som læser sidder tilbage med et væld af spørgsmål, man forgæves søgte besvaret i teksterne på baggrund af indledningens anslag.

Bogens forsøg på at gøre op med „vestlig teoretisk dominans“ synes dermed at have slået fejl.

Signe Borch

Antropolog, ph.d.-stipendiat

Göteborgs Universitet

INA KJØGX PEDERSEN: Samles, skilles ad. Erindringer om liv og død i Sønderho. København: Gyldendal 2010. ISBN 978-87-02-08237-1. Pris: 299 kr.

Denne bog er en indfødts forsøg på at udforske og så konkret som muligt at formidle, hvad det vil sige at „komme fra et sted“. Stedet er Fanø - endnu en $\varnothing$ i antropologien, kunne man sige - mere præcist byen Sønderho (med ca. 300 indbyggere) på øens sydspids.

Forfatteren Ina Kjøgx Pedersen (Ina) arbejder som journalist på Weekendavisen, men er desuden uddannet antropolog. Som bogens undertitel siger, er der tale om en erindringsbog, men den er samtidig antropologisk relevant, uanset at forfatteren ikke selv betegner sin bog som et antropologisk værk.

Bogen opdeles i to dele med titlerne „Mit“ og „Vores“. Første del, som udgør cirka en tredjedel, omhandler Inas eget tidlige liv og hendes slægtsbaggrund. De sidste to tredjedele, „Vores“, omhandler så godt som det samme: Ina er blevet ældre, og der er lidt mere fokus på de kulturelle manifestationer og traditioner, som udgør omdrejningspunkterne for tilhørsforholdet. Bogens mindste enheder er de små betitlede afsnit på to-tre sider, som 10-12 styk sammen udgør bogens større kapitler, med titler som „Andre ord“, „Slægten“, „At begå sig“ m.m. 